\title{
Magnetotelluric (MT) and Resistivity Survey along Belsara-Rasunpur Traverse Delineating Conductivity Structure over Bakreswar Geothermal Region in Birbhum District, West Bengal
}

\author{
D.C. Naskar \\ Geophysics Division, Eastern Region, Geological Survey of India, India
}

Copyright $\bigcirc 2017$ by authors, all rights reserved. Authors agree that this article remains permanently open access under the terms of the Creative Commons Attribution License 4.0 International License

\begin{abstract}
Magnetotelluric (MT) and resistivity methods have been carried out over the geothermal region of Bakreswar, West Bengal to obtain a preliminary idea about the nature of conductivity structure and to prepare a meaningful conceptual model of the geothermal region. One conductive anomaly zone is mapped along resistivity traverse Bakreswar-Asanshuli at " $\mathrm{n}$ " (separation parameter) $=10$ in between 1200-1500 m station. Bakreswar hot spring lies adjacent to it and geologically it may be the source of it controlled by hidden fault. In resistivity traverse from Chandrapur to Tantipara, the presence of subsurface conductive bodies (50-400 Ohm-m) mapped between stations $1000-1200 \mathrm{~m}$ at a pseudo depth of $400-700 \mathrm{~m}$. This may be the structural breaks like shear zones/geothermal region. The high resistive layer below conductive layer is interpreted by MT survey at a depth of 3001-38103 m showing its occurrence at a shallow depth of $3001 \mathrm{~m}$ at Rajnagar but a greater depth of $38103 \mathrm{~m}$ at Nakrakonda. This steep gradient in between these two stations could possibly be attributed to a fault zone. Similar type of fault is inferred in between Belsara (7484 m) and Nakrakonda (38103 m). The steep gradient observed between stations also may be coincident with the postulated fault plane. One highly conductive zone is observed in MT pseudo-sections, which may be due to the geothermal zone in the area. Some static shift is evident from the vertical elongations of the apparent resistivity contours (zone of weakness) between Idgachha to Rasunpur region which are not reflected in the phase pseudo-sections. This may be due to the presence of faults/lineament/fracture/shear zone. A high conductive feature is inferred beneath Lokpur and Idgachha region extending from shallow surface into the deep crust. The lower crust in the entire study area is rather conductive whereas the upper crust is resistive.
\end{abstract}

Keywords Bengal Basin, Bakreswar Geothermal
Region, Magnetotelluric Sounding, DC Resistivity Profiling, 1-D Model, 2-D Model

\section{Introduction}

West Bengal generated about 7620 MWe of electricity in 2012-2013 from coal based power plants, 16 MWe from biomass and 4.3 MWe from wind. The amount of $\mathrm{CO}_{2}$ emission from the power plants, assuming $978 \mathrm{~kg} \mathrm{CO}$ /MWh is about 7 million $\mathrm{kg}$. Although West Bengal has excellent, high temperature geothermal system at Bakreswar, the state government and the energy policy makers did not see or recognize this resource. Further, Tantloi geothermal site which falls in the state of Jharkhand is located only a few kilo meters north of Bakreswar in West Bengal. Besides heat, the gases associated with the geothermal system are enriched with helium. The Bakreswar thermal power plant located a few kilometers from the geothermal site is generating 1050 MWe. This paper reports the details of Bakreswar and Tantloi geothermal sites in West Bengal and Jharkhand-West Bengal state border. The Bakreswar-Tantloi geothermal sites located along the SONATA lineament that hosts similar kind of geothermal systems. These sites are located very near to the Bakreswar coal based thermal power plant that is generating $7620 \mathrm{MWe}$ of electricity emitting about 7 million $\mathrm{kg} \mathrm{CO}_{2}$. The geothermal sites as discussed above can support part of the present demand thus reducing about 1 million $\mathrm{CO}_{2}$ emissions. This will help the rural population to get clean energy and replace the current practice of generating power from biomass.

Geochemistry of thermal springs located at Bakreswar (West Bengal) and Tantloi (Jharkhand) geothermal fields are issuing through Precambrian granites that are enriched in radioactive elements like uranium, thorium and potassium. 
The helium and radon emanations in the thermal gases are $3 \%$ have been drilled at Tantloi to decipher the sub-surface $\mathrm{v} / \mathrm{v}$ and $885 \mathrm{kBq} / \mathrm{m}^{3}$ respectively. Considering the fluid flow rate, radioactive element content in the granites, geothermal gradient and heat flow values, these sites can generate minimum of about $500 \mathrm{MWe}$.

Bakreswar geothermal areas are located in the Chota Nagpur Gneissic Complex (plateau) predominantly comprising granitic rocks (Precambrian) with a discontinuous stretch of coal bearing Gondwana sedimentary (Lower Permian to Middle Jurassic). Geothermal manifestation in this area is the form of copious discharge of hot water of about $780 \mathrm{l} / \mathrm{min}$ through several spouts. The water temperature as measured in the surface varies from $35^{\circ}$ to $88^{\circ} \mathrm{C}$ (Ravi Shanker, 1991) [19]. In fact there are four channels of hot springs in the entire region which is called as Bakreswar-Tantloi groups. Two boreholes $(<200 \mathrm{~m}$ deep) geology. The boreholes yield continuous discharge of hot water of $65^{\circ} \mathrm{C}$ with profuse steam. The geothermal gradient measured in two boreholes is $90^{\circ} \mathrm{C} / \mathrm{km}$ and the reported heat flow value is $200 \mathrm{~mW} / \mathrm{m}^{2}$ (Shankar, 1988) [21]. Literature on deep geophysical exploration over the Indian geothermal areas is not easily available. Magnetotelluric (MT) survey is widely carried out at different parts of the world for investigation of the geothermal provinces (Keller, 1978) [11]. MT and resistivity geophysical methods have been carried out in the geothermal region of Bakreswar, West Bengal (Fig. 1; Location of the MT observation site and resistivity profile in Bakreswar geothermal region) to obtain a preliminary idea about the nature of conductivity structure and to prepare a meaningful conceptual model of the geothermal region.

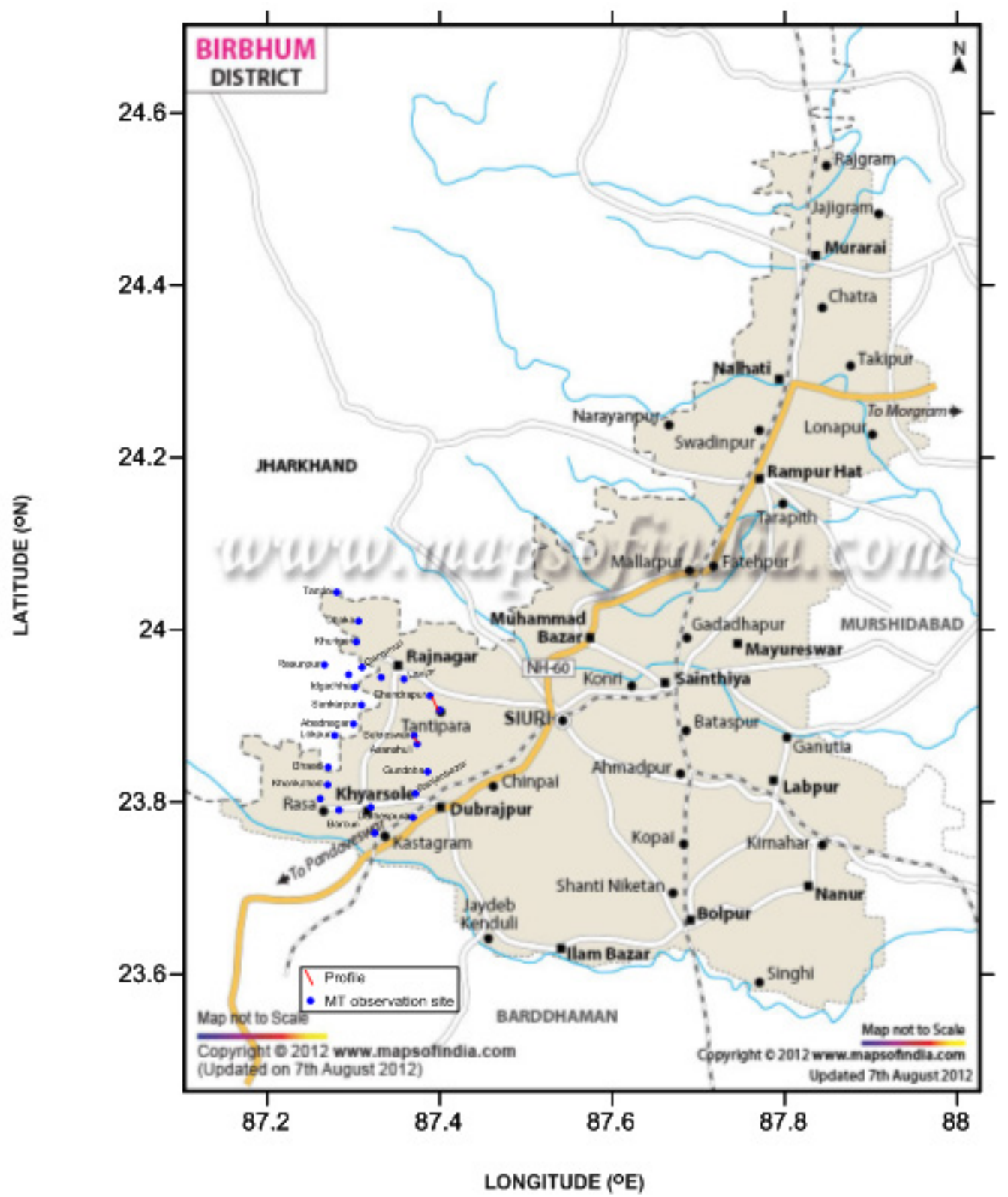

Figure 1. Location of the MT observation site and resistivity profile in Bakreswar geothermal region 


\section{Tectonic and General Geology}

The SONATA lineament that extends from Gujarat to west Bengal is a mega-mid-continent lineament and represents a major suture zone. The well-known Tattapani thermal springs are located over this lineament (Chandrasekharam and Antu, 1995 [3], Chandrasekharam, 2000 [1], 2005 [2], Chandrasekharam and Chandrasekhar, 2010 [4], Minissale et al., 2000) [15]. This lineament extends eastwards towards Jharkhand and West Bengal and is cut by an N-S trending fault. Precambrian granites and gneisses, Gondwana sedimentary rocks and Rajmahal volcanics characterize this region. The Bakreswar and Tantloi thermal springs flow along the N-S trending fault that cuts the main mega SONATA lineament (Nagar et al., 1996 [18], Singh et al., 2014 [22]). The N-S fault is characterized by silicification and brecciation, that can be traced over $1.4 \mathrm{~km}$. The overall geological formations are similar to that of Tattapani, located over the SONATA lineament (Chandrasekharam and Antu, 1995 [3], Minissale et al., 2000 [15]). The Bakreswar geothermal area (Fig. 2; Regional geological setting of the geothermal areas in Eastern India. Map is not to scale.) had been subjected to different cycles of tectonic disturbances under periods of isostatic readjustments from Precambrian to Cenozoic times (Ravi Shanker, 1991) [19]. Afterwards formation of new fractures/reactivation of old fractures in the basement crystalline had been taken place (Deb and Mukherjee, 1969) [2]. These fractures control deep circulation of meteoric water and subsequent thermal discharges for several groups of geothermal areas in the Chota Nagpur granite gneissic complex (CGGC) in eastern India. In the absence of reliable geochronological data from the basement comprising of gneisses, metasediments and high-grade granulite facies rocks, early history of the crystalline complex is obscure. However, the age of younger intrusive and extrusive rocks are known by reliable radiometric datings. A geological history of over 2 billion years has been traced and the terrain remained active until $65 \mathrm{Ma}$. The absence of lithological and structural details, identity of individual basins from vast terrain, caused evaluation of early history $(>1.7 \mathrm{Ga})$ speculative to construct a meaningful stratigraphy. The CGGC apparently forms lithotectonic assemblages that have undergone polyphase deformation, metamorphism and magmatism. This has resulted in the recognition of boundaries notably in the northern and southern margins of
CGGC with less certainty.

The CGGC gives evidence of recording three tectono thermal events inferred from petrological and limited geochronological dates available from basement lithology. The proto-crust or the base of the CGGC has been inferred from the study of metapelitic clasts (K-feldspar-sillimanite muscovite-biotite schist, at Inderwa, Koderma) set in a conglomerate of granodiorite matrix at the base of the Bihar Mica Belt (BMB), a sub-basin of CGGC, showing basement-cover relationship. In view of $1590 \pm 30 \mathrm{Ma}$ of intrusive granite in the $\mathrm{BMB}$, the age of an earlier tectonothermal event as indicated by the metapelite has been correlated with similar activities at $\sim 2.1 \mathrm{Ga}$ in the Central Indian Tectonic Zone (CITZ) - a Proterozoic metamorphic belt in Central India. The earliest pre-Mesoproterozoic magmatic rocks and the protoliths are difficult to recognize in the CGGC because of the imprint of later regional scale metamorphic events.

The thermal springs of Bakreswar occur in a topographically low lying area hosted in a gently rolling terrain which is mostly filled by alluvial or lateritic soil with sporadic exposures of basement crystalline. The basement is predominantly composed of granite gneiss with minor enclaves of calc-silicate, amphibolite, gabbro, pegmatite and dolerite (dyke) - all belong to the Precambrian CGGC. The gneiss and calc-silicate are regionally folded to form asymmetric to symmetric anticlinal and synclinal structures trending NE-SW (Nagar et al., 1996) [18]. The spring site is situated in the trend of a nearly $\mathrm{N}-\mathrm{S}$ striking buried fault sometimes represented by scanty exposures of brecciated and silicified rocks occurring in narrow zone traceable for about $2 \mathrm{~km}$ in the north of the springs. A pilot plant to extract helium from the thermal gases at Bakreswar was installed and this extraction plant demonstrated the feasibility of extracting helium from geothermal gases and purifying the same to $99.9 \%$ on a commercial basis. Even the soils around these sites are enriched in helium and the helium content in the soils varies from 46 to 83 ppm (Nagar et al., 1996 [18]; Chandrasekharam, 2000 [1]). Very high He and very low $\mathrm{Kr} / \mathrm{Xe}$ ratio (0.262) in the gases suggests the source for these elements to be the basement granites (Ghose and Chatterjee, 1980 [7]; Ghose et al., 1989) [9]. Geological succession in Bakreswar geothermal region after Mukhopadhyay, 1996 [17] Table 1: 


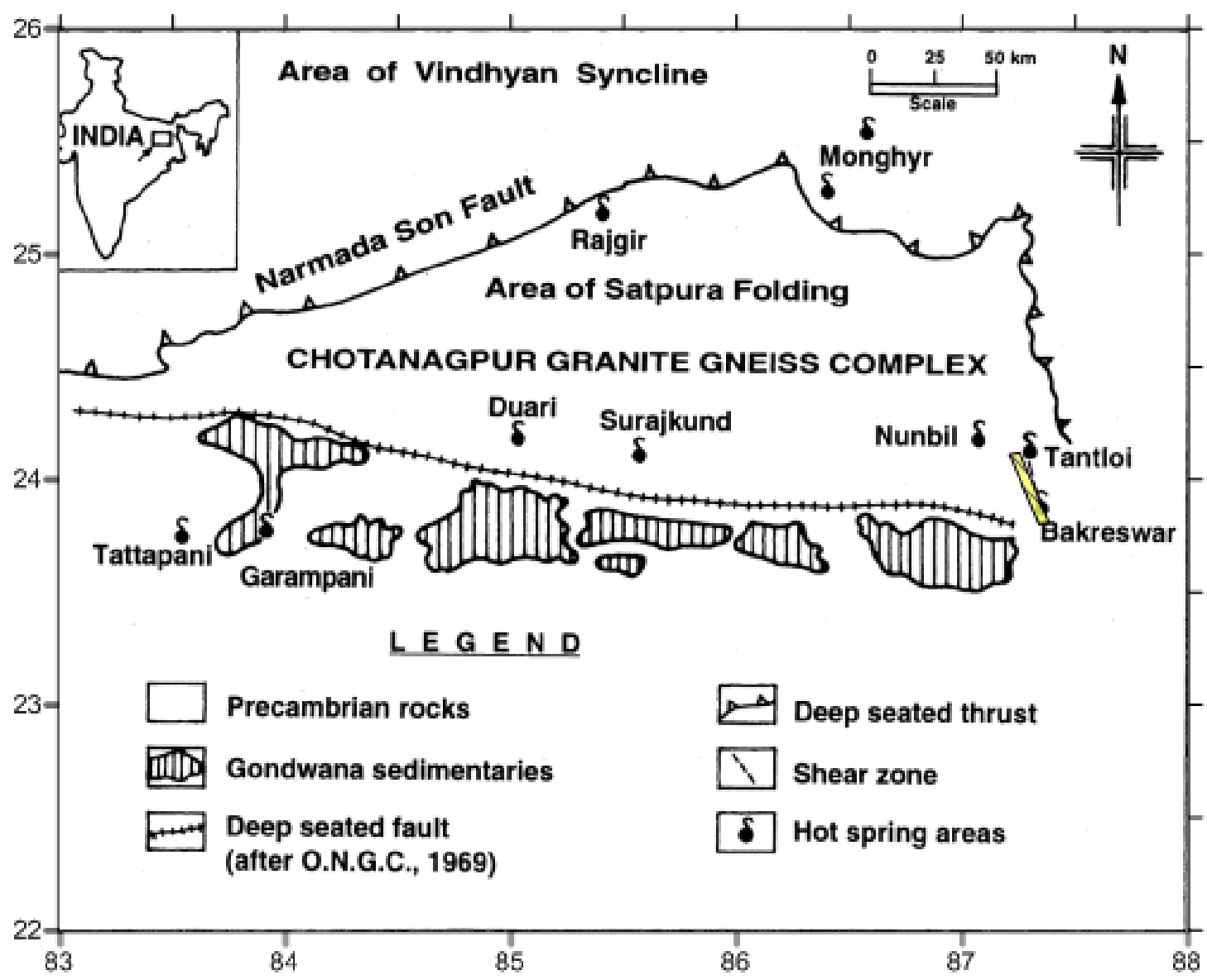

\section{Area surveyed}

Figure 2. Regional geological setting of the geothermal areas in Eastern India. Map is not to scale.

Table 1. Geological succession in Bakreswar-Tantloi geothermal region after Mukhopadhyay, 1996) [10]:

\begin{tabular}{|c|c|}
\hline Recent/Quaternary & Alluvium \\
\hline \multicolumn{2}{|l|}{ Unconformity } \\
\hline & Laterite \\
\hline \multicolumn{2}{|l|}{ Unconformity } \\
\hline \multirow{3}{*}{ Lower Gondwana } & Dolerite dyke \\
\hline & Barakar sandstone (gritty, felspahic) \\
\hline & Talchir shales, sandstone and boulder bed \\
\hline Lower to Middle Proterozoic & $\begin{array}{c}\text { Manbhum granite/Kuilipal granite - porphyritic granite containing phenocrysts of feldspar } \\
\text { Dalma volcanics - mafics and ultramafics } \\
\text { Singhbhum Group - High grade mica schist, phyllites, quartzites, ultramafics and felsic rocks, tuffs, cherts, and calc } \\
\text { silicates }\end{array}$ \\
\hline $\begin{array}{l}\text { Chota Nagpur gneissic } \\
\text { complex }\end{array}$ & Unclassified metamorphic/anorthosites (Bankura, Purulia) \\
\hline Precambrian & $\begin{array}{l}\text { Pegmatite with quartz vein, metadolerite, porphyritic granite, granite gneiss, migmatite with horneblende gneiss, } \\
\text { amphibolite, quartzite, calc gneisses, granulites and charnockites. }\end{array}$ \\
\hline
\end{tabular}




\section{Review of the Earlier Geological \& Geophysical Work in Bakreswar Geothermal Region}

Several workers have investigated group of hot springs from time to time, dealing with their geological mode of occurrence and chemical composition (Mukherjee, 1967) [16], geo-chemistry (Chowdhury et al., 1964) [5], genesis (Deb and Mukherjee, 1969) [6], and natural gases with special reference to helium emanation (Ghose et al., 1994) [8], isotopic composition (Majumdar et al. 1998) [12], and geothermal energy potential (Mukhopadhyay, 1996) [17]. Most of the previous works are restricted to surface studies and little is known about the subsurface geology related to the hot spring activity.

Based on mixing hydrology and chemical equilibrium, it was suggested that a group of alkaline thermal springs, having varying temperatures $\left(45-71^{\circ} \mathrm{C}\right)$ and identical compositions emerges through a nearly $\mathrm{N}-\mathrm{S}$ trending fault in the gneissic basement (Majumdar et al., 2005) [14]. Geoelectric investigations reveal the presence of two to four prominent lithologic layers under prevailing hydrodynamic conditions (Majumdar et al., 2000) [13]. On the basis of magnetic and electrical studies done by the Atomic Minerals Division (Calcutta), Nagar et al. 1996 [18] have suggested the presence of a N-S trending fault extending for about 2 $\mathrm{km}$ in this area. Analysis of magnetotelluric data as a reconnaissance indicates two low resistive zones of thicknesses $2.3 \mathrm{~km}$ and $3.4 \mathrm{~km}$ at a depth of $8 \mathrm{~km}$ and $12 \mathrm{~km}$ respectively (Sinha Ray, et al., 2001 [23]; Shalivahan, 2004 [20]).

\section{Theory and Technique of MT Survey}

Magnetotellurics are natural source electromagnetic (EM) method. EM wave of atmospheric and ionospheric origins are used as the source field for audio-magnetotelluric (AMT) and MT surveys respectively. Varying source magnetic field $(\mathrm{H})$ induces an electric field (E) in the earth structure and they are related to each other by the equation:

$$
\mathrm{E}=\mathrm{ZH}
$$

Here $Z$, the impedance tensor, represents the electrical properties of the subsurface. Entire time series data set is divided into several segments depending upon the frequency of interest and spectral estimates of each segment are calculated by Fourier transform. Impedance tensors for each frequency have been estimated from the measured field vectors using the following equation:

$$
Z_{\mathrm{ij}}(\omega)=\mathrm{E}_{\mathrm{i}}(\omega) / \mathrm{H}_{\mathrm{j}}(\omega)
$$

Where $\mathrm{i}$ and $\mathrm{j}$ indicates two mutually perpendicular directions in horizontal plane and ' $\omega$ ' the angular frequency. Apparent resistivity $\left(\rho_{\mathrm{a}}\right)$ and phase $(\phi)$ are calculated from the values of $Z$. At a particular frequency, they can be expressed as follows:

$$
\begin{gathered}
\rho_{\text {aij }}=0.2 / \mathrm{f}\left|\mathrm{Z}_{\mathrm{ij}}\right|^{2} \\
\phi_{\mathrm{ij}}=\tan ^{-1} \operatorname{Im}\left|\mathrm{Z}_{\mathrm{ij}} / / \operatorname{Re}\right| \mathrm{Z}_{\mathrm{ij}} \mid
\end{gathered}
$$

$\mathrm{E}$ and $\mathrm{H}$ fields are measured along two orthogonal axes during AMT and MT data acquisition. During modeling and interpretation, one of the axes of measurement is to be oriented along the geoelectric strike direction for simplicity. The direction of strike is determined from the impedance tensor. Depending upon the orientation of measured electric field there are two modes in AMT and MT soundings, transverse electric (TE) or E-parallel and transverse magnetic (TM) or E-perpendicular. TE mode anomaly is inductive in nature as the telluric current flows along the structure whereas TM modes anomaly is galvanic. They show different sensitivity at different depth depending upon the nature of conductivity structure.

\subsection{Data Acquisition}

Using the state-of-the-art digital data acquisition system ADU $06 \& 07$ by Metronix, Germany, 11 stations were occupied for the period of 5 days in each station. The location map of MT sites is shown in Fig. 1; Location of the MT observation site and resistivity profile over Bakreswar geothermal region. The equipment used is a portable system and powered with $12 \mathrm{~V}$ battery and incorporate latest electronics. Magnetic field sensors consist of wide band induction magnetometer coils with very low noise. Three such sensors are used to measure the orthogonal components $\left(\mathrm{H}_{\mathrm{x}}, \mathrm{H}_{\mathrm{y}}\right.$ and $\left.\mathrm{H}_{\mathrm{z}}\right)$ of earth's magnetic field variation. The frequency band of signals ranges from $20 \mathrm{kHz}$ to $0.00025 \mathrm{~Hz}$. The electric field sensors are non-polarizing electrodes with $\mathrm{Pb}-\mathrm{PbCl}_{2}$ and are used for measuring two orthogonal components $\left(\mathrm{E}_{\mathrm{x}}\right.$ and $\left.\mathrm{E}_{\mathrm{y}}\right)$ of telluric field. The wide frequency range of measurement is divided into 7 bands, with each band of data selected at a time.

\subsection{Data Processing}

MT data was processed using MAPROS software provided by Metronix. It includes the Fast Fourier components to transfer the data from time domain to frequency domain and is stacked at the prescribed frequencies. $E_{x}(\omega), E_{y}(\omega), H_{x}(\omega), H_{y}(\omega)$ and $H_{z}(\omega)$ are stacked. MAPROS software provides mean and standard deviation of all the apparent resistivity and phase from the stacked values to get impedance tensor elements $Z_{x x}, Z_{y y}, Z_{x y}$ and $Z_{\mathrm{yx}}$. Frequency variation of apparent resistivity and phase are obtained in both TE and TM modes. The processed data is modeled using 1D module, pseudo-section module, and 2D inversion module of WinGLink software.

\subsection{Discussion of Results}

The location map of the study area (Fig. 1; Location of 
the MT observation site and resistivity profile over Bakreswar geothermal region.) shows MT soundings (11 nos.) and resistivity profiling (2 nos.). The resistivity/conductivity of rocks is an important parameter for mapping large-scale crustal structures, which may provide a clue on the processes of crustal evolution. Subsurface resistivity distribution will be directly related to the physical characters of the lithological units. Variation in resistivity of the rocks is the main source of electrical anomaly.

\subsection{Representative Time Series Data}

Fig. 3 a, b; Time series HF band and LF2 band data of station Nakrakonda. Low frequency signal is picked up due to the continuous recording of data for a period of 5 days. Fig. 4 a, b; Unrotated and rotated MT data (apparent resistivity and phase) of station Nakrakonda. Fig: a presents unrotated data; Fig. b presents rotated data (Swift, 1967 [24]; Vozoff, 1972 [25]) for TE and TM mode apparent resistivities and their phases.

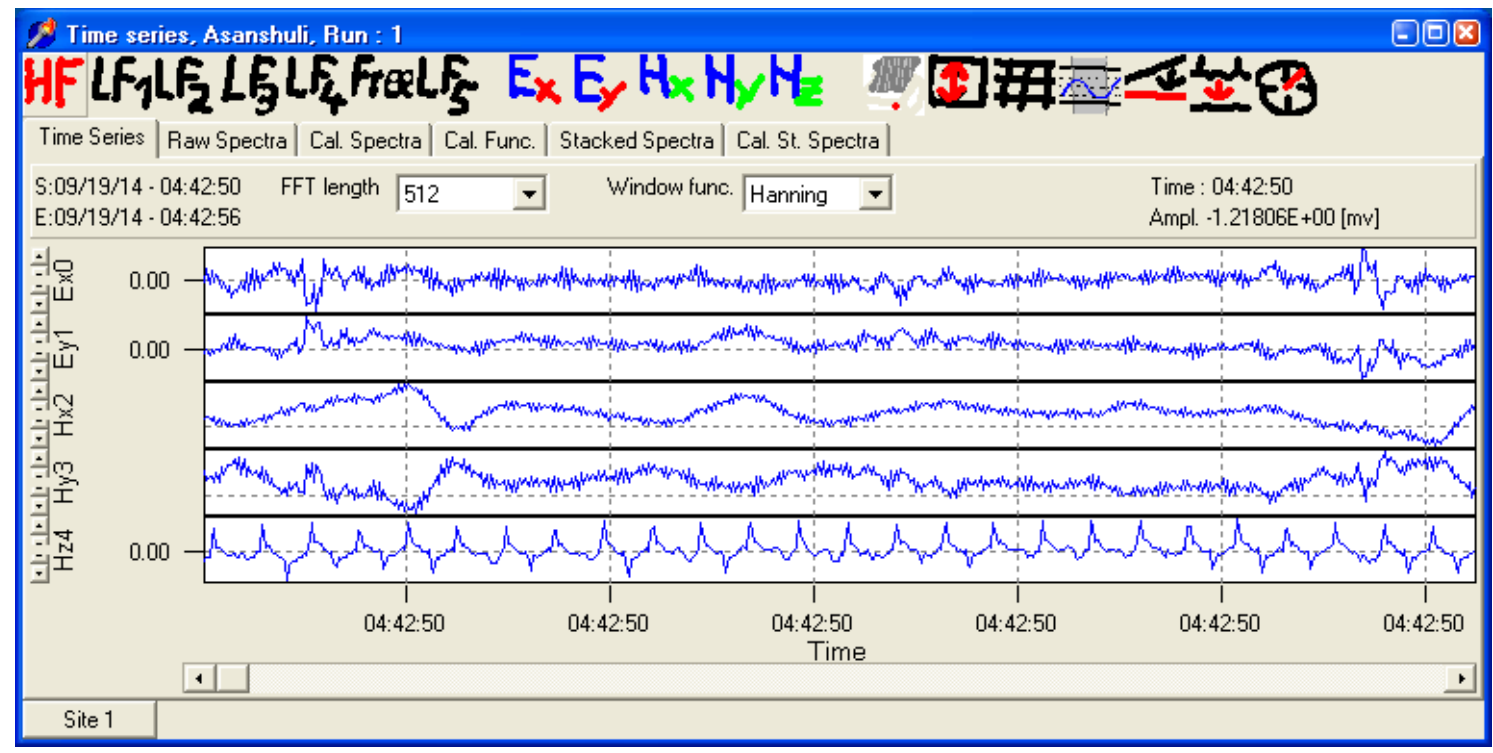

Figure 3a. Time series data of station Nakrakonda in HF band

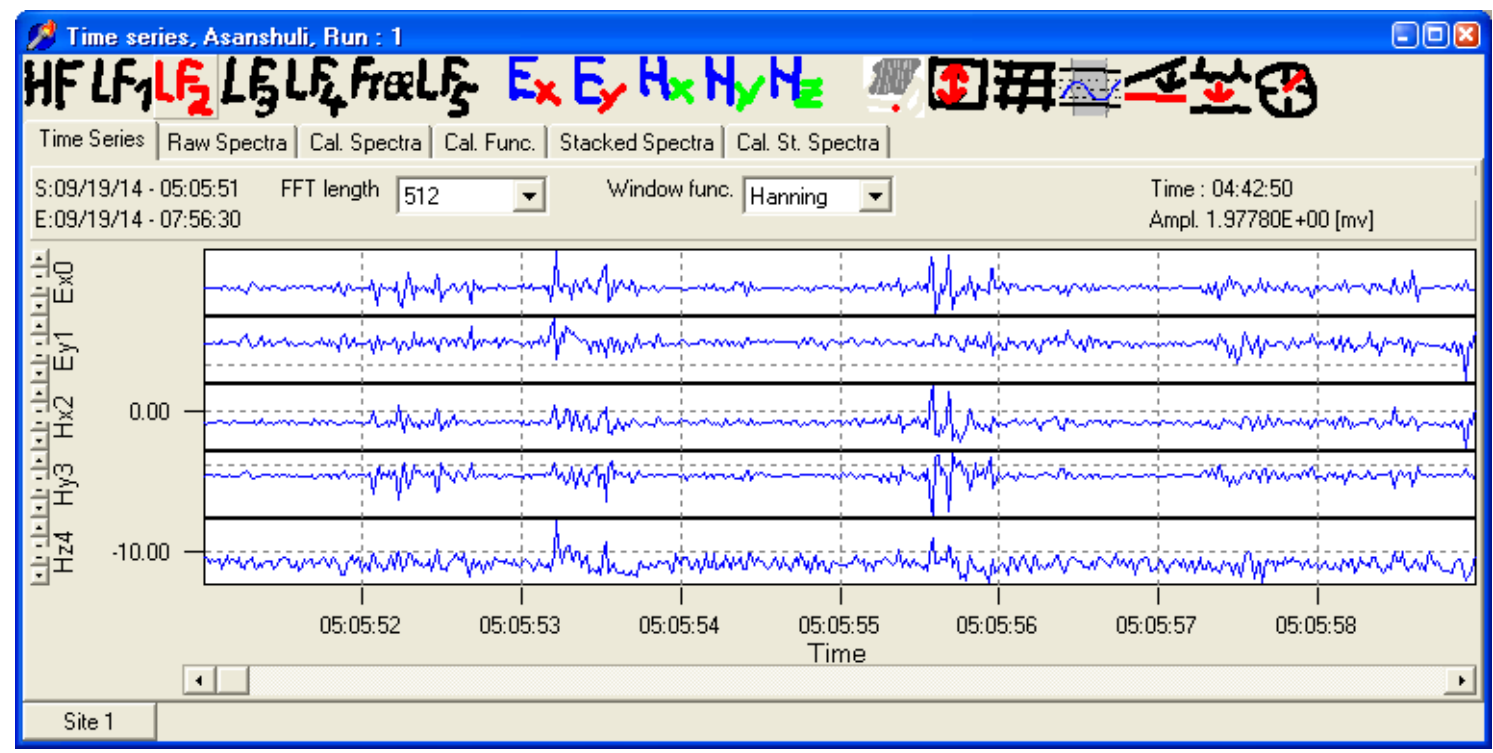

Figure 3b. Time series data of station Nakrakonda in LF2 band 


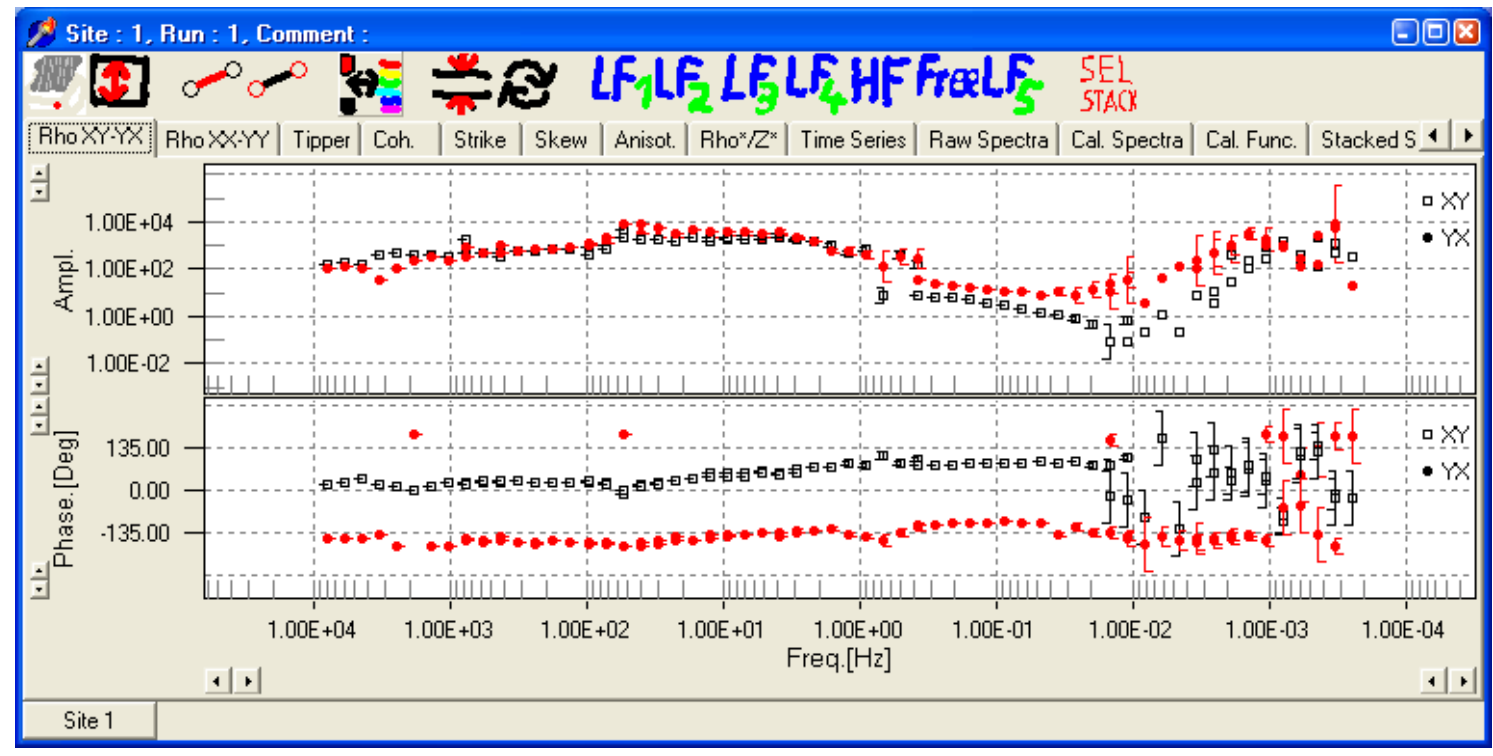

Figure 4a. Unrotated MT data (apparent resistivity and phase) of station Nakrakonda

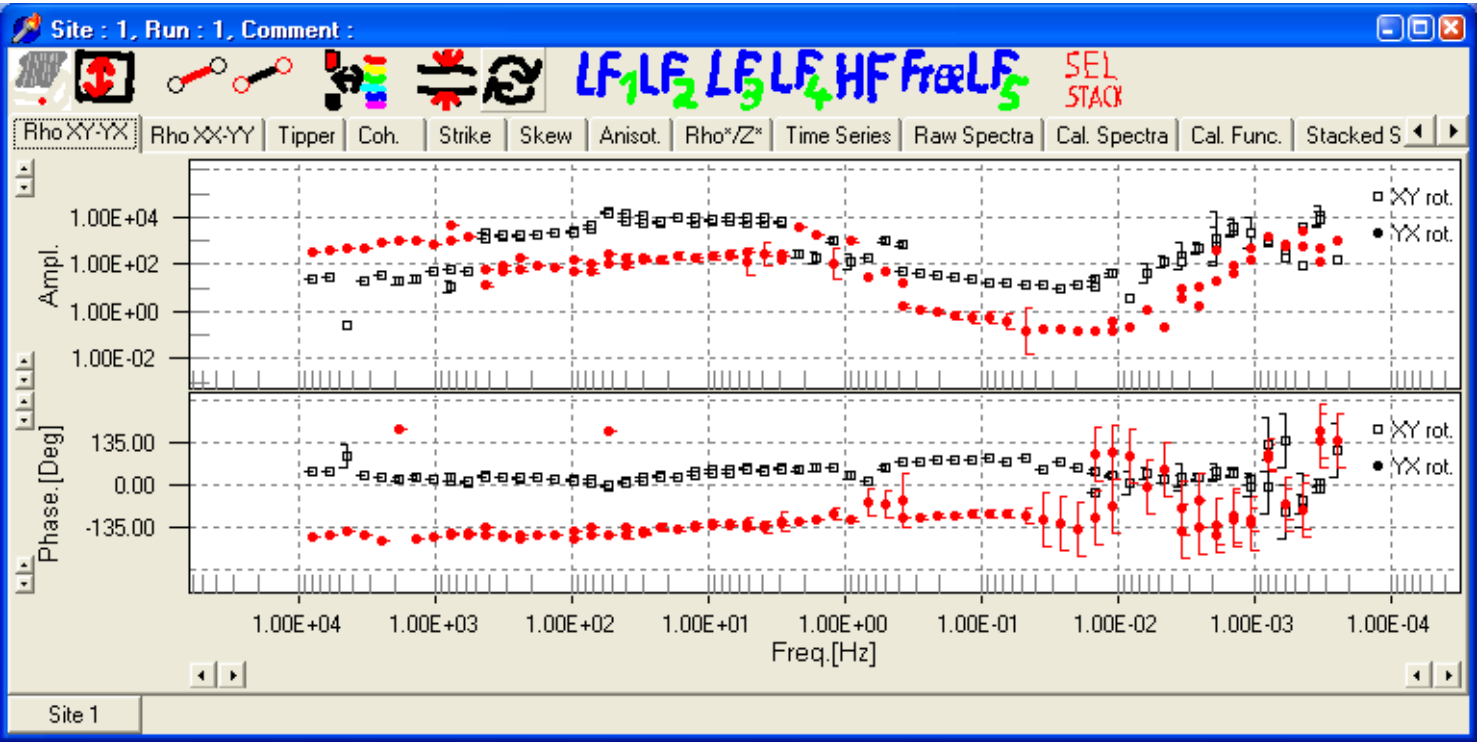

Figure 4b. Rotated MT data (apparent resistivity and phase) of station Nakrakonda

\subsection{1-D Model of MT Sounding Data}

As a first step of quantitative interpretation of MT sounding curves, 1-D modeling was carried out using both Bostick and Occam of WinGLink program to obtain the resistivity and thickness parameters of different layers for each sounding. In general, a five layer sequences are obtained for most of the MT soundings by 1-D inversion. The interpreted resistivity and thickness parameters of the layered sequences are listed in Table 2. The top layer indicates a resistivity range of 2-108 $\mathrm{Ohm}-\mathrm{m}$ with a thickness of $2 \mathrm{~m}$ to $816 \mathrm{~m}$. The second layer is characterized by resistivity in the range of 10-10000 Ohm-m with a large variation in thickness from $1 \mathrm{~m}$ to $3272 \mathrm{~m}$. The third layer indicates a resistivity range of 4-78000 Ohm-m with a thickness of $653 \mathrm{~m}$ to $29018 \mathrm{~m}$. The fourth layer appears to be a conductive layer with a resistivity of 1-92 Ohm-m and thickness in the range of $1443 \mathrm{~m}$ to $9016 \mathrm{~m}$. The last layer indicates a resistive horizon at a variable depth of 2999-38101 $\mathrm{m}$. The detailed analysis of few representatives MT sounding are shown in figures $5 \mathrm{a}, 5 \mathrm{~b}$ and $5 \mathrm{c}$. 

Structure over Bakreswar Geothermal Region in Birbhum District, West Bengal

Table 2. Interpreted results of MT soundings

\begin{tabular}{|c|c|c|c|}
\hline Location/Sounding No. & Resistivity (Ohm-m) & Thickness (m) & Depth (m) \\
\hline \multirow[t]{5}{*}{ Belsara } & 103 & 157 & 157 \\
\hline & 8736 & 3272 & 3429 \\
\hline & 4 & 1790 & 5219 \\
\hline & 8 & 2262 & 7481 \\
\hline & 34274 & - & - \\
\hline \multirow[t]{5}{*}{ Kenan } & 56 & 92 & 92 \\
\hline & 3793 & 2740 & 2832 \\
\hline & 6 & 1711 & 4543 \\
\hline & 67 & 6383 & 10926 \\
\hline & 12142 & - & - \\
\hline \multirow[t]{4}{*}{ Nakrakonda } & 91 & 27 & 27 \\
\hline & 2801 & 40 & 67 \\
\hline & 78000 & 29018 & 29085 \\
\hline & 92 & 9016 & 38101 \\
\hline \multirow[t]{5}{*}{ Kharikabad } & 10 & 35 & 35 \\
\hline & 23 & 26 & 61 \\
\hline & 8677 & 16906 & 16967 \\
\hline & 27 & 2894 & 19861 \\
\hline & 90000 & - & - \\
\hline \multirow[t]{5}{*}{ Bhaadi } & 20 & 23 & 23 \\
\hline & 467 & 79 & 102 \\
\hline & 4307 & 6579 & 6681 \\
\hline & 30 & 3223 & 9904 \\
\hline & 1731 & - & - \\
\hline \multirow[t]{5}{*}{ Lokpur } & 30 & 14 & 14 \\
\hline & 519 & 173 & 187 \\
\hline & 6472 & 1878 & 2065 \\
\hline & 7 & 2068 & 4133 \\
\hline & 2644 & - & - \\
\hline \multirow{3}{*}{ Abadnagar } & 10898 & 1079 & 3395 \\
\hline & 1 & 2010 & 5405 \\
\hline & 903 & - & - \\
\hline \multirow{5}{*}{ Shankarpur } & 5 & 2 & 2 \\
\hline & 286 & 73 & 75 \\
\hline & 994 & 8596 & 8671 \\
\hline & 40 & 6894 & 15565 \\
\hline & 1740 & - & - \\
\hline \multirow[t]{5}{*}{ Idgachha } & 11 & 27 & 27 \\
\hline & 2127 & 1374 & 1401 \\
\hline & 738 & 653 & 2054 \\
\hline & 24 & 4870 & 6924 \\
\hline & 16000 & - & - \\
\hline \multirow[t]{5}{*}{ Rajnagar } & 2 & 4 & 4 \\
\hline & 40 & 1 & 5 \\
\hline & 1227 & 1551 & 1556 \\
\hline & 3 & 1443 & 2999 \\
\hline & 1200 & - & - \\
\hline \multirow[t]{5}{*}{ Rasunpur } & 37 & 25 & 25 \\
\hline & 233 & 158 & 183 \\
\hline & 3151 & 2600 & 2783 \\
\hline & 7 & 2384 & 5167 \\
\hline & 2953 & - & - \\
\hline
\end{tabular}




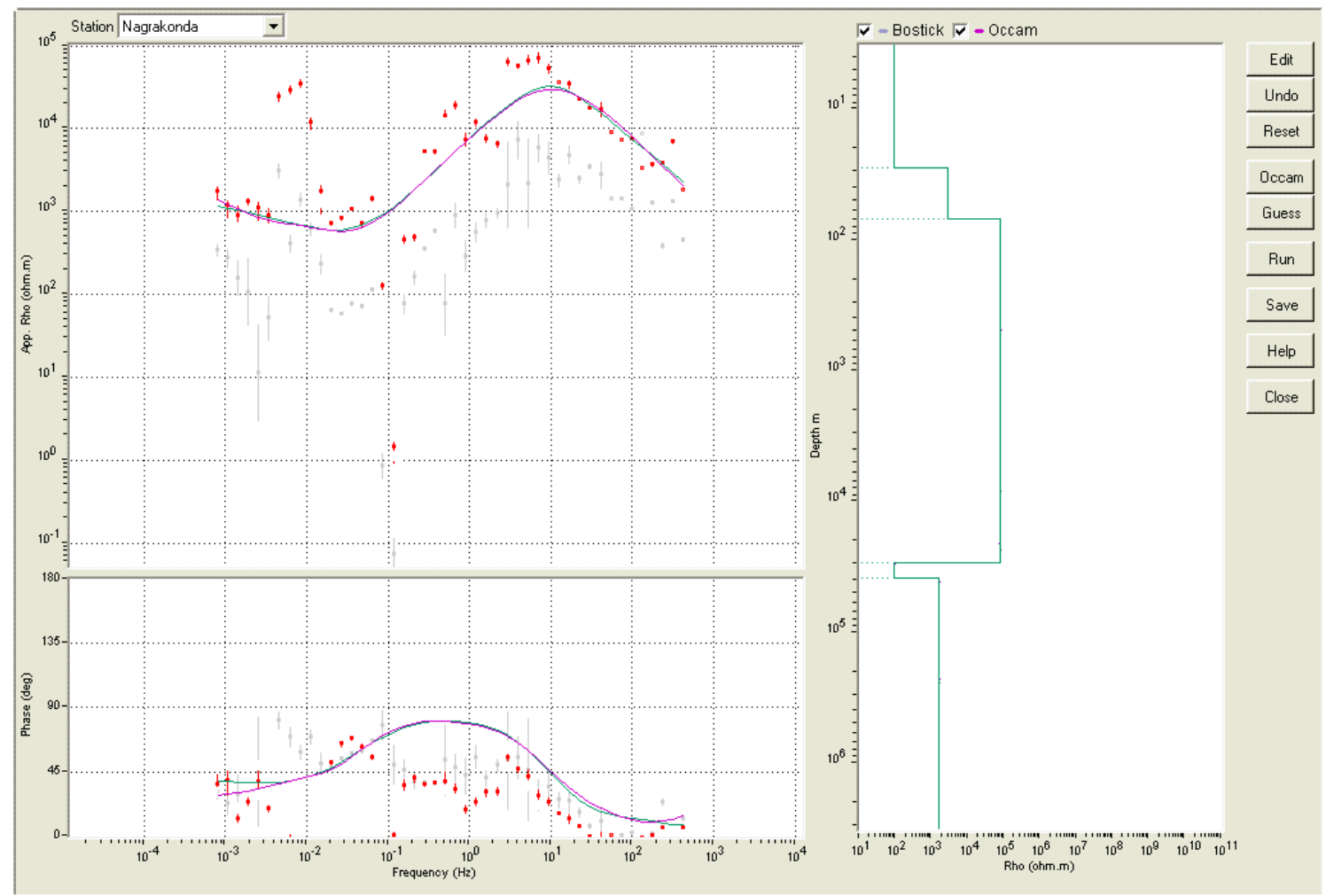

Figure 5 a. 1-D inversion of station Nakrakonda with interpreted layer parameters

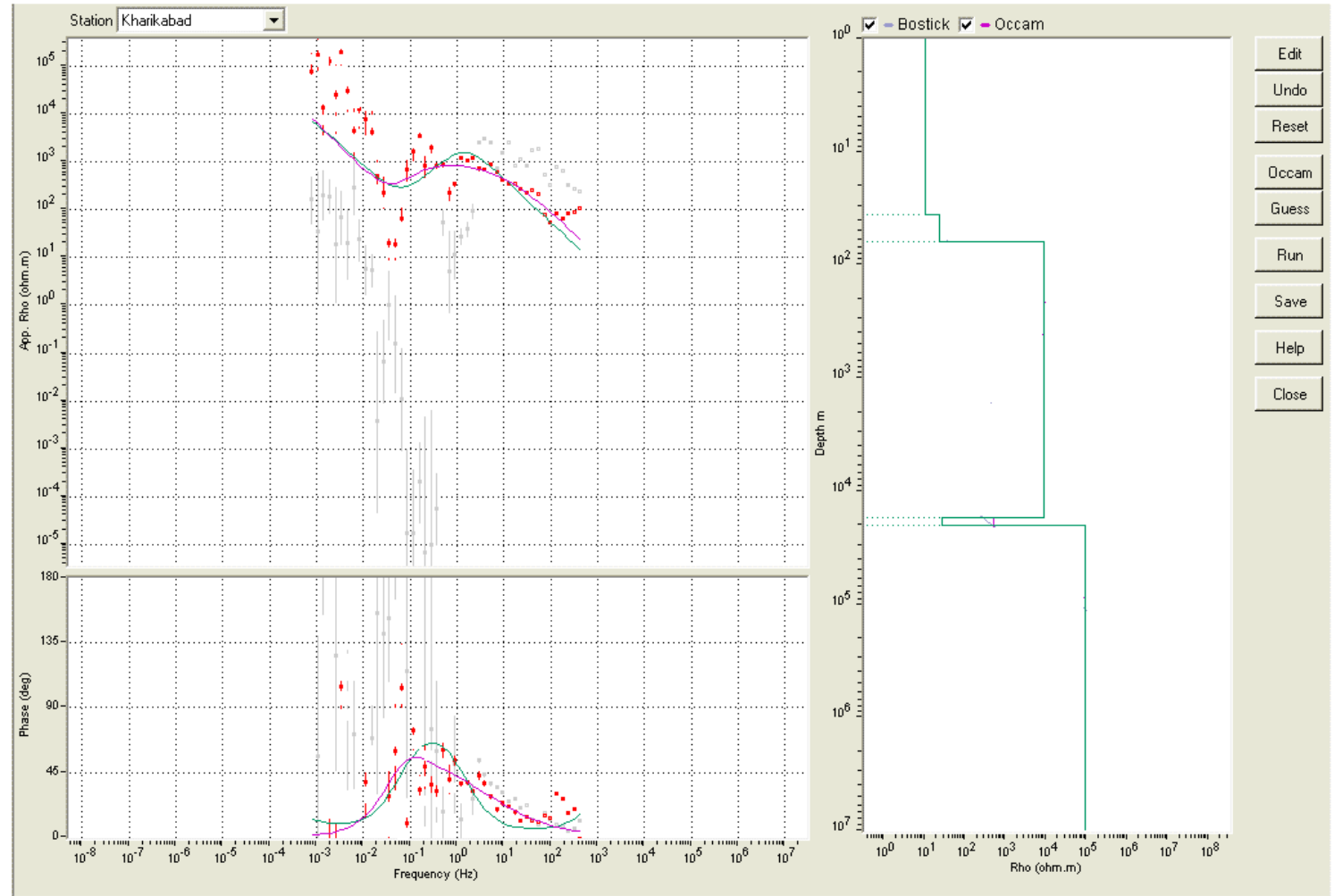

Figure 5 b. 1-D inversion of station Kharikabad with interpreted layer parameters 


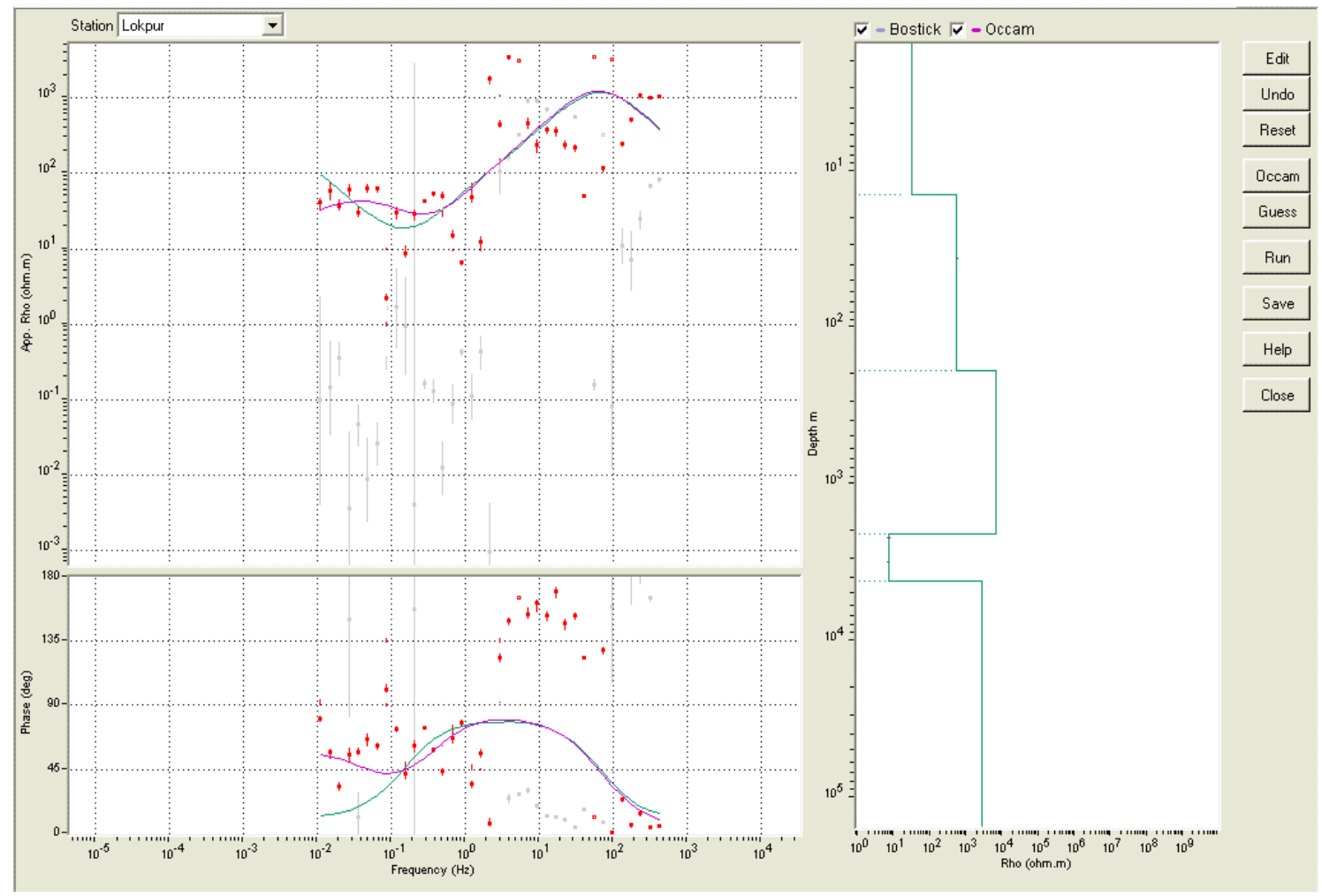

Figure 5 c. $\quad 1-D$ inversion of station Lokpur with interpreted layer parameters

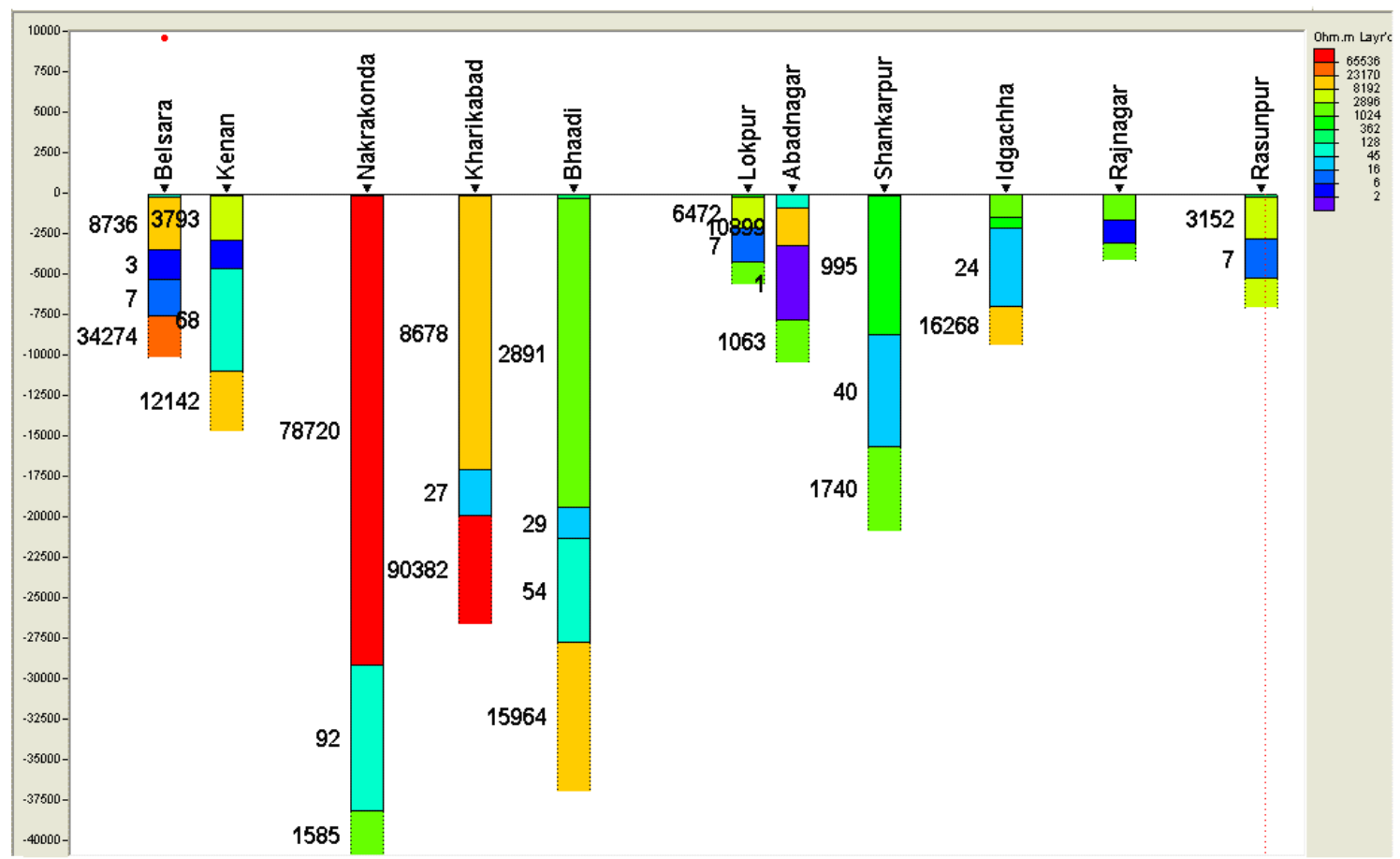

Figure 6. TE mode 1-D geo-electric sections along Belsara-Rasunpur traverse (vertical scale: depth in m). Resistivity values are in Ohm-m 


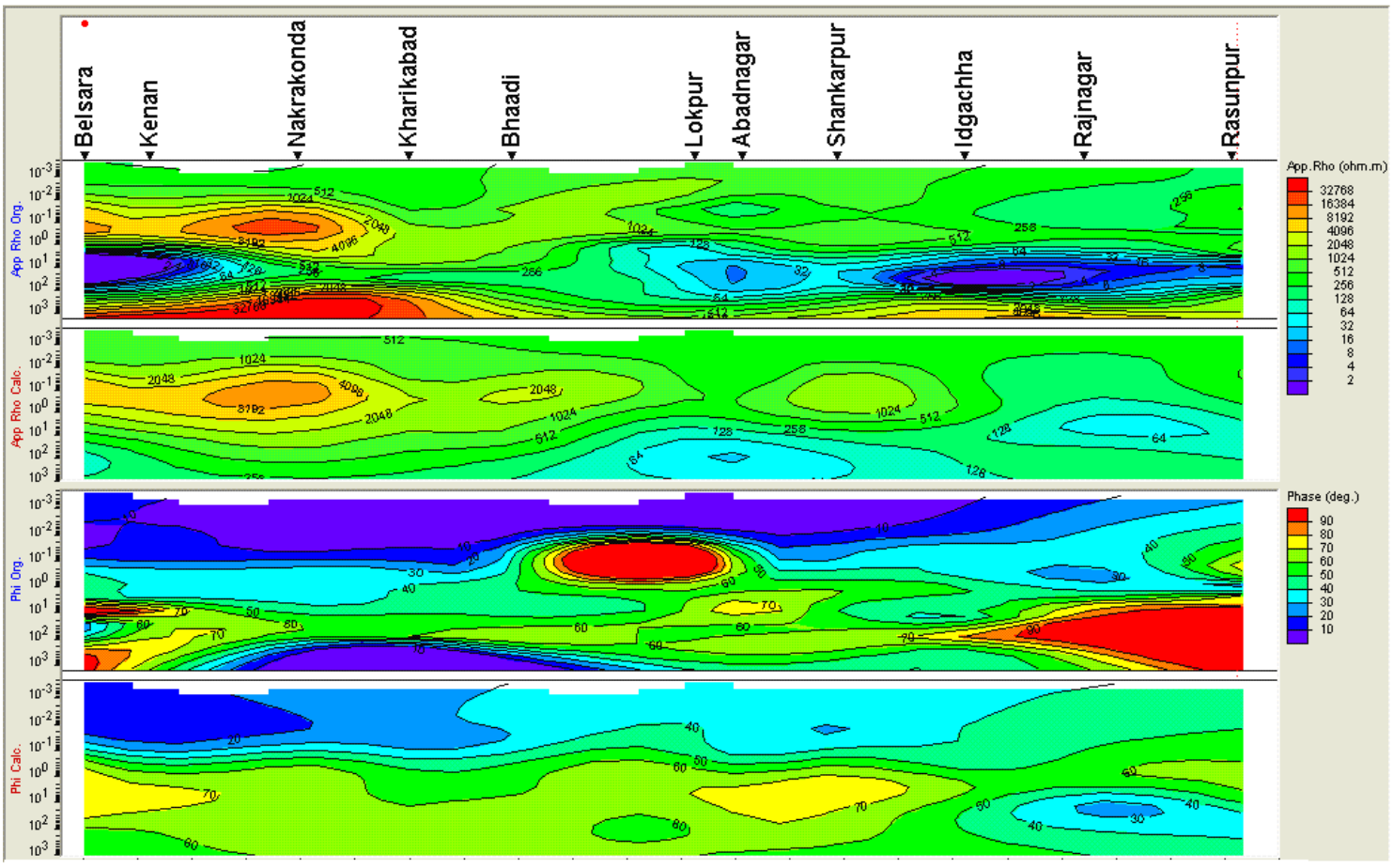

Figure 7. The apparent resistivity and phase pseudo-sections along Belsara-Rasunpur traverse

\subsection{Geoelectric Section along Belsara-Rasunpur Traverse}

The interpreted vertical resistivity distribution along Belsara-Rasunpur traverse is shown in Fig. 6; TE mode 1-D geo-electric sections along Belsara-Rasunpur traverse (vertical scale: depth in $\mathrm{m}$ ). Resistivity values are in Ohm-m. MT sounding was conducted along this traverse. Vertical resistivity distribution is shown using Bostick and Occam 1-D model. The subsurface layers are characterized by different resistivity values. The highly resistive crystalline layer below the top-soil is characterized by resistivity varying from $103-78720 \mathrm{Ohm}-\mathrm{m}$ and of thickness varying from 1552-29059 $\mathrm{m}$ at a depth level varying from surface to $93 \mathrm{~m}$. The highly conductive layer is clearly brought out below the resistive crystalline rock in all the MT soundings. It is characterized by resistivity ranging from 1-92 Ohm-m and thickness varying from 1443-9016 $\mathrm{m}$ as well as depth varying from $1557-29087 \mathrm{~m}$. The high resistivity layer is interpreted at a depth level varying from 3001-38103 m. The high resistivity layer comes up to a shallow depth $(3001 \mathrm{~m})$ at station Rajnagar whereas the same occurs at a greater depth (38103 m) at Nakrakonda. The steep gradient in between station Rajnagar and Nakrakonda could possibly be attributed to a fault zone. Another fault is inferred due to steep gradient of high resistivity in between Belsara (7484 m) and Nakrakonda (38103 m).

\subsection{MT Pseudo-section along Belsara-Rasunpur Traverse}

The apparent resistivity and phase pseudo-sections along the Belsara-Rasunpur traverse (Fig. 7; The apparent resistivity and phase pseudo-sections along Belsara-Rasunpur traverse) confirm the similar subsurface set up as shown in the 1-D geoelectric section. They are plotted with rotated $\rho_{\mathrm{xy}}, \varphi_{\mathrm{xy}}$ and $\rho_{\mathrm{yx}}, \varphi_{\mathrm{yx}}$ values. The ordinate represents the time period of the MT signals. The contour values show the apparent resistivity and phase. High resistive zone is observed throughout the section up to 10 seconds in observed field apparent resistivity pseudo-section. One highly conductive zone of apparent resistivity 2-32 $\mathrm{Ohm}-\mathrm{m}$ is observed in between 10-100 seconds throughout the observed field apparent resistivity pseudo-section except Nakrakonda to Bhaadi. Afterwards the high resistive zone is underlain beyond 100 seconds throughout the section. The calculated apparent resistivity pseudo-section indicates a zone of weakness (static shift followed by apparent resistivity $256 \mathrm{Ohm}-\mathrm{m}$ ) supported by vertical elongations of contours running from Rajnagar in the north to Nakrakonda in the south downthrown towards the southern side and corroborated with the 1-D MT section. This may be due to the presence of faults/lineament/fracture/shear zone and accumulation of electric charges along them/faulted boundary. Apparent resistivity pseudo-sections are better suited for the detection of faults. The signature of the faults extends to longest period as indicated in the pseudo-section.

The impression of high resistivity (low phase angle) zone is observed in observed and calculated phase pseudo-sections up to 0.1 second throughout the section. Afterwards the low resistive zone is inferred in between 0.1 to 1000 second supported by high phase angle. The pseudo-sections show some lateral phase variations at long time period MT signals. The phase of the impedance is not 
affected by the near surface inhomogeneities by frequent fluctuations in phase contours and at the same time most of the information on the sub-structure is available in the apparent resistivity is also available in the phase data. However, information on the resistivity levels is not available in the phase data. But the calculated phase pseudo-section is not in agreement with the calculated apparent resistivity pseudo-section regarding static shift problem/zone of weakness and which is the case may be. Moreover the observed apparent resistivity and phase pseudo-sections corroborate well/same signatures by the impressions of opposite color code.

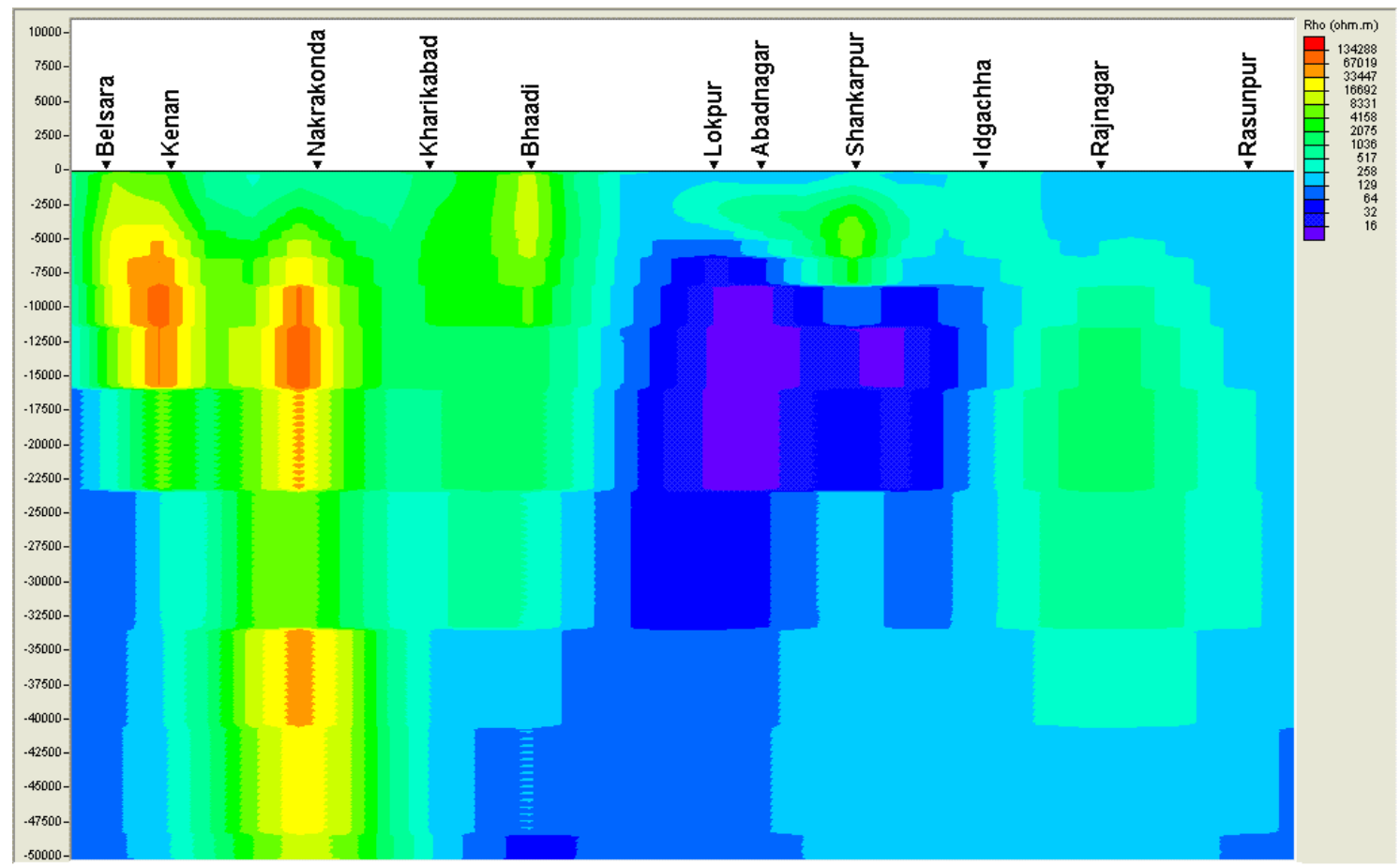

Figure 8. 2-D model along Belsara-Rasunpur traverse

\subsection{2-D Model along Belsara-Rasunpur Traverse}

The MT data were inverted using the inversion method to generate 2-D subsurface conductivity distribution in the area. These results are depicted in Fig. 8; 2-D model along Belsara-Rasunpur traverse. One prominent high resistive zone is observed in between Belsara to Bhaadi starting from shallow surface to higher depth. Another high resistive zone is inferred below Idgachha. Two prominent faulted boundaries/contacts are depicted in between Bhaadi to Lokpur and Idgachha to Rajnagar respectively. The cross-section also shows a highly conductive feature beneath north of Bhaadi and Idgachha region extending from shallow subsurface $(5 \mathrm{~km})$ into the deeper crust. Studies over subducting plates in several parts of the world have revealed similar high conductivity layers. The high conductivity at lower levels below Lokpur to Idgachha may be attributed to several causative factors. Attempts have been made to explain these deep crustal conductors on the basis of the water percolation through the lineaments/faults/fractures or on the basis of the fluids in open pores, partial melting of the deep crustal rocks, possible serpentinisation in the remnants of the oceanic crusts and grain boundary graphite films. Geothermal studies over northern boundary of the pericratonic Bengal basin indicate a high heat flow of about $100 \mathrm{mWm}^{-2}$. High conductivity may have some links with high heat flow in the area. Because the electrical conductivity of the crust mantle silicates has strong dependence on temperature, higher the temperature of the sub-continent higher will be the conductivity. The geothermal study over various parts of sediment cover region indicates a high heat flow of magnitude $100 \mathrm{mWm}^{-2}$. Maximum reported depth of the percolation of water from the surface is about $17 \mathrm{~km}$. However, volatile phases from the mantle viz. $\mathrm{C}, \mathrm{H}, \mathrm{O}, \mathrm{N}$ and $\mathrm{S}$ can come to the lower crustal and upper most mantle level in the form of $\mathrm{CO}_{2}, \mathrm{CH}_{4}$ and $\mathrm{H}_{2} \mathrm{O}$ phases. The lower crust in the entire profile is rather conductive whereas the upper crust in between Rasunpur to Belsara is resistive. It is thus possible that the entire crust may be highly conductive, intruded by high resistivity block.

\section{Theory and Technique of Resistivity Survey}

The collinear dipole-dipole array was used for observing the subsurface electrical discontinuities in the profiling mode. This method employs constant dipole length "a". Increased 
depth of penetration is achieved by increasing the separation of the transmitting and receiving dipoles at intervals of " $n$ ", where $n=1,2,3 \ldots$ etc. The upper limit of " $n$ " is determined by the maximum depth of interest and signal to noise ratio. If "I" be the current injected and "V" be the potential difference measured, the apparent resistivity is

$$
\begin{gathered}
\rho_{\mathrm{a}}=\mathrm{K} \mathrm{V} / \mathrm{I}=\pi \mathrm{an}(\mathrm{n}+1)(\mathrm{n}+2) \mathrm{V} / \mathrm{I} ; \mathrm{K} \text { is geometric factor for } \\
\text { this array configuration }
\end{gathered}
$$

Hallof (1957) [10] introduced the concept of plotting the profiling data over a traverse in the form of vertical pseudo-section in resistivity survey for dipole-dipole array. The apparent resistivity values are plotted at the point of intersection of the $45^{\circ}$ lines from the two dipole centre right below the centre of the array.

\subsection{Data Acquisition}

A Scintrex 3 KVA time domain resistivity unit was used for the field survey as a transmitter. The grounded or current sending electrodes were made up of steel stake rod. IPR-10A receiver of the Scintrex make was used for measuring the potential. Non polarisable electrodes (copper in saturated copper sulphate solution) were used as potential electrodes for the survey.

\subsection{Results of Resistivity Profiling}

Dipole-dipole profiling was conducted along two traverses of length $2 \mathrm{~km}$ each from Bakreswar-Asanshuli and Tantipara-Chandrapur (Fig. 1; Location of the MT observation site and resistivity profile over Bakreswar geothermal region). The results of the survey have been analyzed.

\subsubsection{Resistivity Profiling along Bakreswar-Asanshuli Traverse}

To delineate the conductive feature in the Bakreswar geothermal region, a geoelectric traverse is laid over a length of $2 \mathrm{~km}$ with a=100 m and "na" separation of $1300 \mathrm{~m}$. The resistivity pseudo-section is shown in the Fig. 9; Collinear dipole-dipole resistivity profiling along Bakreswar-Asanshuli traverse. The average order of apparent resistivity in the alluvial cover varies from 100 Ohm-m in near surface to about $1800 \mathrm{Ohm}-\mathrm{m}$ at depth around $700 \mathrm{~m}(\mathrm{n}=13)$ and beyond. The first layer is characterized by apparent resistivity of $100 \mathrm{Ohm}-\mathrm{m}$ may be the top soil in the area which is followed by a layer of apparent resistivity $200 \mathrm{Ohm}-\mathrm{m}$. These are followed by a layer of resistivity $400 \mathrm{Ohm}-\mathrm{m}$ which is underlain by a high resistive layer. Continuous increasing resistivity is observed depth wise throughout the section. One conductive anomaly zone is mapped at $\mathrm{n}=10$ in between $1200-1500 \mathrm{~m}$ station. The actual resistivity of the causative body is expected to be much lower than the contour value of apparent Resistivity $100 \mathrm{Ohm}-\mathrm{m}$ which defines the source within a resistive host rock $(1800 \mathrm{Ohm}-\mathrm{m})$. The actual nature of the causative body is unknown. Bakreswar hot spring lies adjacent to it and geologically it may be the source of hot spring controlled by hidden fault.

\subsubsection{Resistivity Profiling along Chandrapur-Tantipara Traverse}

Bakreswar-Tantloi sector was chosen for deep electrical studies primarily to understand the nature of causative source responsible for geothermal activities in this area. A traverse of $2 \mathrm{~km}$ length was laid along Chandrapur-Tantipara section and was observed with dipole length of $100 \mathrm{~m}$ with "na" separation of $1600 \mathrm{~m}$. Fig. 10; Collinear dipole-dipole profiling along Chandrapur-Tantipara traverse represents the dipole-dipole pseudo-section which brings out a couple of high resistive zones remarkably two in between station $200-1000 \mathrm{~m}$ and $1200-2000 \mathrm{~m}$ at a pseudo depth of $400-800 \mathrm{~m}$ and $500-800 \mathrm{~m}$ respectively. The causative source of high values of resistivity at a depth of 400-800 m might represent dolerite dykes/unaltered granite gneiss. Of particular importance in this traverse is the presence of subsurface conductive bodies (50-400 Ohm-m) mapped between station 1000-1200 m at a pseudo depth of 400-700 m. This may be due to the structural breaks like shear zones/geothermal region. In view of hot spring activities in nearby area of Bakreswar, such subsurface conductors assume greater significance as a geothermal region. First $100 \mathrm{~m}$ may represent top soil/laterite cover followed by a conductive layer up to $300 \mathrm{~m}$. 


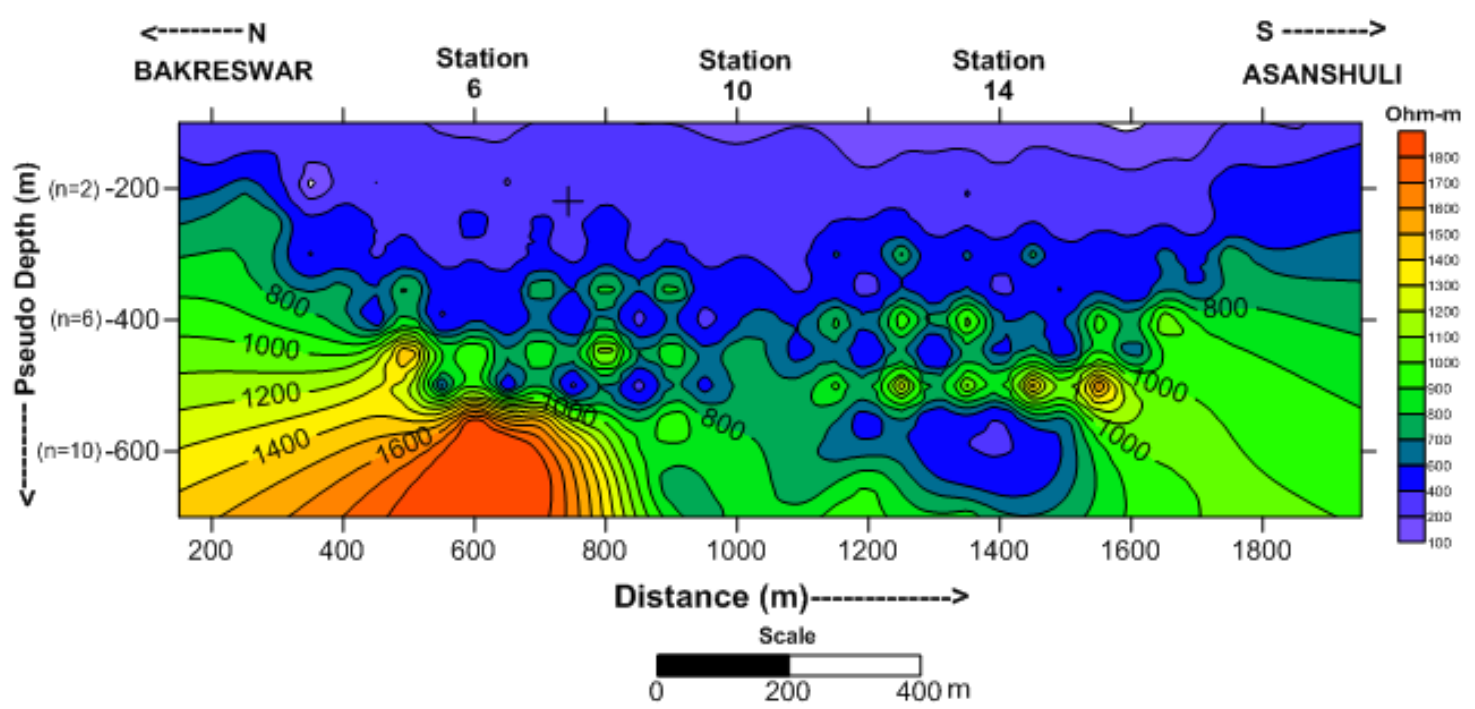

Figure 9. Collinear dipole-dipole resistivity profiling along Bakreswar-Asanshuli traverse

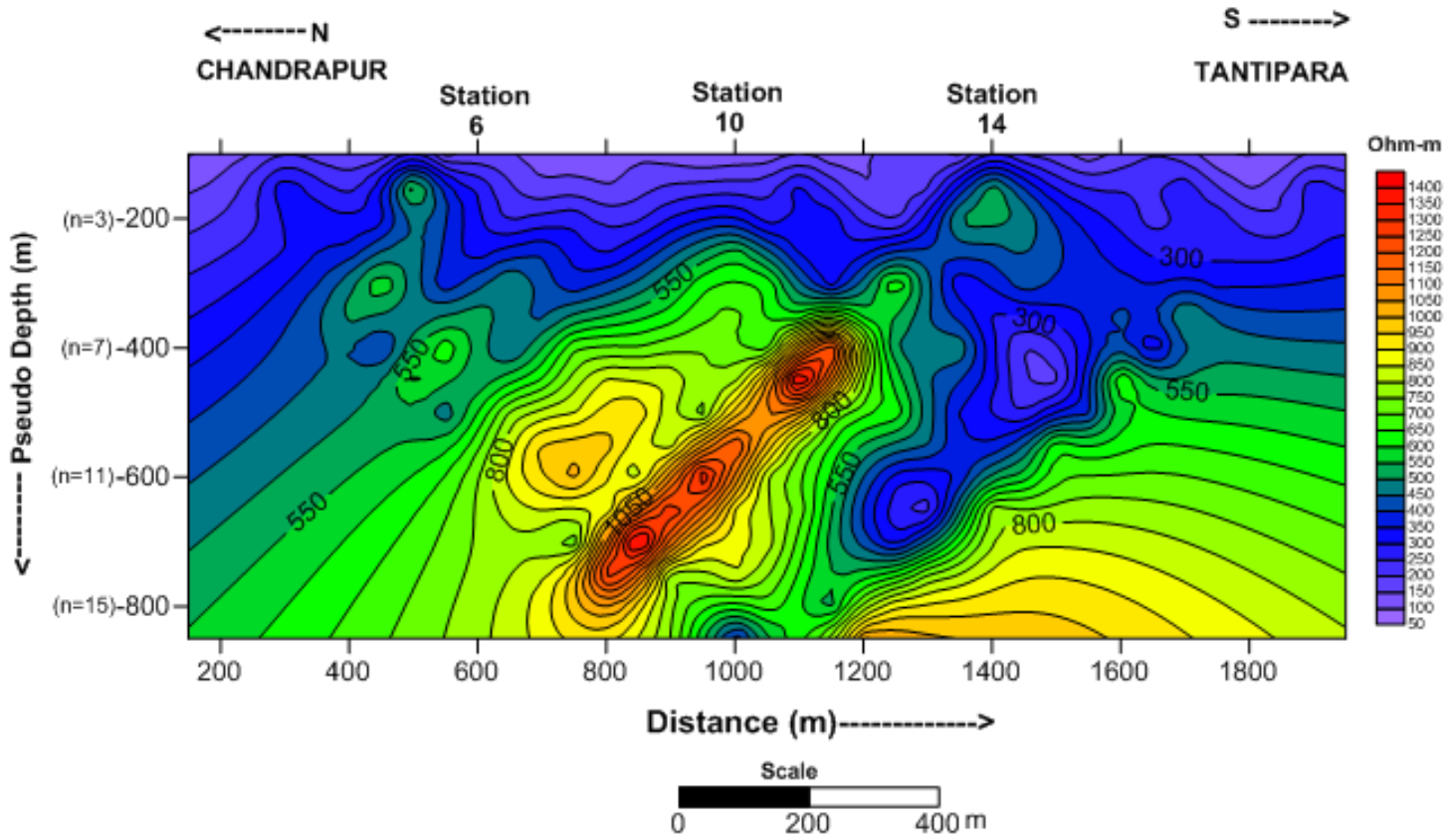

Figure 10. Collinear dipole-dipole profiling along Chandrapur-Tantipara traverse

\section{Conclusions}

In MT survey the high resistive compact crystalline rock is present below the soil cover of resistivity varying from 800-78000 Ohm-m and thickness varying from 1552-29059 $\mathrm{m}$. Highly conductive zone is clearly brought out below the resistive crystalline rock in almost all the MT soundings. It is characterized by resistivity ranging from $1-55 \mathrm{Ohm}-\mathrm{m}$ and thickness varying from 1443-9016 $\mathrm{m}$ which is followed by a high resistive layer of varying depth $3000-38103 \mathrm{~m}$. The highly conductive layer is interpreted at a depth of 3001-38103 m showing its occurrence at a shallow depth of $3001 \mathrm{~m}$ at Rajnagar but a greater depth of $38103 \mathrm{~m}$ at Nakrakonda and 7484-38103 m showing its occurrence at a shallow depth of $7484 \mathrm{~m}$ at Belsara but a greater depth of
$38103 \mathrm{~m}$ at Nakrakonda. The steep gradient in between these stations could possibly be attributed to fault zone. The steep gradient observed between stations may be coincident with the postulated fault plane.

One highly conductive zone is observed in MT pseudo-sections, which may be due to the geothermal zone in the area. Some static shift is evident from the vertical elongations of the apparent resistivity contours (zone of weakness) between Idgachha to Rasunpur which are not reflected in the phase pseudo-sections. This may be due to the presence of faults/lineament/fracture/shear zone.

A high conductivity feature is inferred beneath Lokpur and Idgachha region extending from shallow surface into the deep crust. The lower crust in the entire study area is rather conductive whereas the upper crust is resistive respectively. 
It is thus possible that the entire crust may be highly conductive, intruded by high resistive block.

In resistivity traverse from Bakreswar to Asanshuli, one conductive anomaly zone is mapped at $n=10$ in between $1200-1500 \mathrm{~m}$ station. The actual resistivity of the causative body is expected to be much lower than the contour value of $100 \mathrm{Ohm}-\mathrm{m}$ which defines the source within a resistive host rock $(1800 \mathrm{Ohm}-\mathrm{m})$. The actual nature of the causative body is unknown. Bakreswar hot spring lies adjacent to it and geologically it may be the source of hot spring controlled by hidden fault. In resistivity traverse from Chandrapur to Tantipara, the presence of subsurface conductive bodies (50-400 Ohm-m) mapped between station 1000-1200 $\mathrm{m}$ at a pseudo depth of $400-700 \mathrm{~m}$. This may be the structural breaks like shear zones/geothermal region. In view of hot spring activities in nearby area of Bakreswar, such subsurface conductors assume greater significance as a geothermal region.

\section{REFERENCES}

[1] Chandrasekharam, D., 2000 Geothermal energy resources of India-Country update. Proceedings World Geothermal Congress 2000, Kyushu-Tohoku, Japan, May 28-June 10, $133-145$.

[2] Chandrasekharam, D., Antu, M.C., 1995 Geochemistry of Tattapani thermal springs, Madhya Pradesh, India-field and experimental investigations. Geothermic. 24(4), 553-559.

[3] Chandrasekharam, D., 2005 Geothermal Energy Resources of India: Past and the Present. Proceedings World Geothermal Congress Antalya, Turkey, 24-29 April 2005.

[4] Chandrasekharam, D. and Chandrasekhar, V., 2010 Hot dry rock potential in India: Future road map to make India energy Independent. World Geothermal Congress 2010, Bali, Indonesia, 25-29 April 2010.

[5] Chowdhury, A.N., Bose, B.B. and Banerjee, G., 1964 Studies on geochemistry of thermal springs at Bakreswar. Proc. 22nd IGC, Part 12, 143-160.

[6] Deb, S. and Mukherjee, A.L., 1969 On the genesis of a few groups of thermal springs in the Chota Nagpur Gneissic Complex, India. J. Geochem. Soc. India 4, 1-9.

[7] Ghose, D., Chatterjee, S.D., 1980 Genesis of the abundance of helium formation in natural gas emanating from thermal springs. Proceeding Indian National Science Academy, Part A 46 (1), 81-83.

[8] Ghose, D., Das, N.K., Sinha, B., Das, S.K. and Chatterjee, S.D., 1994 Heat and helium release from thermal spring and influence of volcanic eruption. Proc. Indian Natl. Sci. Acad. 60 A $2,481-486$.

[9] Ghose, D., Das, S.K., Chatterjee, S.D., 1989 Occurrence of krypton and xenon in the Bakreswar thermal spring gases. Naturwissenschaften 76, 520-521.

[10] Hallof, P.G., 1957 On the interpretation of resistivity and induced polarization results. Doctoral Thesis, Deptt. Geol. \&Geoph., MIT.

[11] Keller, G.V., 1978 Introduction: Special geothermal section. Geophysics, 43, 1449.

[12] Majumdar, N., Mukherjee, A.L., Majumdar, R.K., Navada, S.V. and Sharma, S., 1998 Isotope studies on Bakreswar geothermal area, Birbhum district, West Bengal. Proc. All Ind. Sem. On Development of water resources in India during 50 years since Independence, Ind. Assoc. Hydrol., June 1998, Calcutta. 98-115.

[13] Majumdar, R.K., Majumdar, N. and Mukherjee, A.L., 2000 Geoelectric investigation in Bakreswar geothermal area, West Bengal, India. J. Appl. Geophys. 45(3), 187-202.

[14] Majumdar, N., Majumdar, R.K., Mukherjee, A.L., Bhattacharya, S.K. and Jani, R.A., 2005 Seasonal variations in the isotopes of oxygen and hydrogen in geothermal waters from Bakreswar and Tantloi, Eastern India: implications for groundwater characterization. J. Asian Earth Sci. 25, 269-278.

[15] Minissale, A., Vaselli, O., Chandrasekharam, D., Magro, G., Tassi, F., Casiglia, A., 2000 Origin and evolution of 'intracratonic' thermal fluids from central-western peninsular India. Earth and Planetary Sciences Letters. 181, 377-394.

[16] Mukherjee, A.L., 1967 Major chemical constituents in water from thermal spring areas in the eastern part of Peninsular India and their probable sources. Geochem. Soc. India Bull. 2 3., 45-59.

[17] Mukhopadhyay, D.K., 1996 Geothermal parameters and thermal energy potential of Bakreswar, Tantloi group of hot springs in Birbhum district, West Bengal and Dumka district, Bihar. Proc. Sem. on Geothermal Energy in India. In: Pitale, U.L., Padhi, R.N._Eds.., Geol. Surv. India Pub. 45 pp. 87-98.

[18] Nagar, R.K., Vishwanathan, G., Sagar, S. and Sankaranarayanan, A., 1996 Geological, geophysical and geochemical investigations in Bakreswar - Tantloi thermal field, Birbhum and Santhal Parganas districts, West Bengal and Bihar, India. Proc. Sem. on Geothermal Energy in India. In: Pitale, U.L., Padhi, R.N._Eds.., Geol. Surv. India — Spec. Pub. 45 pp. $349-360$.

[19] Ravi Shanker, 1991 Thermal and crustal structure of ASONATAB: a zone of mid continental rifting in Indian Shield. J. Geol. Soc. India 37, 211-220.

[20] Shalivahan, Sinha Ray, R.K. and Bhattacharya, B.B., 2004 Electrical conductivity structure over geothermal province of Bakreswar, Eastern India. Proc. 17th IAGA WG 1.2 Workshop on Electromagnetic Induction in the Earth, October 18-23, 2004, Hyderabad, India. 6pp. Available at http://www.emindia2004.org/S3-p14_Shalivahan. pdf.

[21] Shanker, R., 1988 Heat-flow of India and discussion on its geological and economic significance. Indian Miner., 42, 89-110.

[22] Singh, H.K., Chandrasekharam, D., Vaselli, O., Trupti, G., Singh, B., Lashin, A., Al Arifli, N., 2014 Physicochemical characteristics of Jharkhand and West Bengal thermal springs along SONATA mega lineament, India. Under review in Journal of Earth System Science.

[23] Sinharay Rajib, K., Shalivahan and Bhattacharya, B.B., 2001 
An analysis of magnetotelluric (MT) data over geothermal region of Bakreswar, West Bengal. Jour. Geophys., XXII (1), 31-39.

[24] Swift, C.M., 1967 A magnetotelluric investigation of an electrical conductivity anomaly in the south-western United
States. Ph.D. thesis, Massachusetts Institute of Technology, Cambridge, M.A., 1967.

[25] Vozoff, K., 1972 Themagnetotelluric method in the exploration of sedimentary basins. Geophysics, 37 (1), 98-141. 